\title{
Growth, Yield and Grain Quality of Pearl Millet (Pennisetum glaucum L.) Genotypes as Influenced by Salinity of Irrigation Water in North Western Regions of India
}

\author{
Govind Makarana ${ }^{*}$, R.K. Yadav², Rakesh Kumar ${ }^{1}$, Ashwani Kumar², \\ P. Sheoran ${ }^{2}$, Gajendra Yadav ${ }^{2}$, Pooja Gupta Soni ${ }^{1}$, Taramani Yadav ${ }^{1}$, Malu Ram Yadav ${ }^{1}$, \\ Manish Kushwaha ${ }^{1}$ and P.B. Gautam ${ }^{2}$ \\ ${ }^{1}$ ICAR-National Dairy Research Institute, Karnal-132001, India \\ ${ }^{2}$ ICAR-Central Soil Salinity Research Institute, Karnal-132001, India \\ *Corresponding author
}

\section{A B S T R A C T}

Poor quality water is adversely affecting the performance of pearl millet crop. Cultivation of salinity tolerant pearl millet may be adapted as strategies for ensuring yield and good quality through effective use of poor quality water. Therefore, we attempted to evaluate the performance of pearlmillet under salinity levels of irrigation water [normal $\left(\sim 0.6 \mathrm{dSm}^{-1}\right)$ and saline 3,6 and $9 \mathrm{dS} \mathrm{m}^{-1}$ water] and two genotypes [AVKB-19 and ICMV-15111]. The maximum plant population per meter row length (11.96, 10.89 and 10.64), maximum No. of leaves/plant (75.06, 44.46 and 68.62), maximum No. of Tillers/plant (7.83, 3.23 and 5.09), highest Plant height $(\mathrm{cm})(194.28,88.49$ and120.5), and highest Stem girth $(\mathrm{mm})(26.38,20.79$ and 23.79) at 50DAS, 30 DA 1st cut and 60 DA 1st cut, respectively recorded under the experimental plots irrigated with good quality water. Among the genotypes, the maximum plant population per meter row length (10.61, 9.65 and 8.90), maximum No. of leaves/plant (64.5, 37.19 and 59.99), highest Plant height $(\mathrm{cm})(182.19,80.6$ and 121.1), and highest Stem girth $(\mathrm{mm})(23.08,17.72$ and 19.48) at 50DAS, $30 \mathrm{DA} 1 \mathrm{st}$ cut and $60 \mathrm{DA} 1 \mathrm{st}$ cut, respectively recorded under the experimental plots with AVKB-19. Maximum No. of Tillers/plant recorded (7.69) with AVKB-19 at 50DAS, but in contrast maximum (2.98 and 4.40 at 30 DA 1 st cut and 60 DA 1 st cut) under ICMV15111. The maximum No. of effective tiller/plant (4.25), highest Ear head length (cm) (27.93), highest Ear head girth $(\mathrm{cm})(8.38)$, maximum 1000-grain weight (gram) (7.35), and maximum No. of grain per Ear head (1869.94) recorded under the experimental plots irrigated with good quality water. Among the varieties, the maximum No. of effective tiller/plant (4.02), highest Ear head length $(\mathrm{cm})$ (26.88), highest Ear head girth $(\mathrm{cm})(7.87)$, maximum 1000-grain weight (gram) (7.25), and maximum No. of grain per Ear head (1612.26) was recorded with AVKB-19. Genotype AVKB-19 produced significantly higher (16.26\%) mean grain yield of $1.93 \mathrm{t} / \mathrm{ha}$ as compared to 1.66 $\mathrm{t} / \mathrm{ha}$ in ICMV-15111. Increase in the salt concentrations of irrigation water from good quality to EC $9.0 \mathrm{dS} / \mathrm{m}$ caused significant decrease in grain yield. The significant reduction $(37.44 \%)$ was observed mainly at the higher salinity $(9 \mathrm{dS} / \mathrm{m})$ of irrigation water compared to the good quality water, whereas, it was 9.90 and $20.80 \%$ at EC 3.0 and $6.0 \mathrm{dS} / \mathrm{m}$, respectively. The maximum value for crude protein content (CP) (10.15\%), Ether extract (EE) (4.39\%), organic matter content (OM) $(97.15 \%)$, and Cell soluble content $(67.32 \%)$ recorded in AVKB-19. In contrast, ICMV-15111recorded maximum value for Dry matter content (DM) $(90.78 \%)$, Ash (3.10\%), Neutral Detergent Fibre (NDF) (34.09), Acid Detergent Fibre (ADF) (6.08\%), Hemicellulose content (HC) (28.51\%) and Total Carbohydrate content (T-CHO) (83.04\%).In general crude protein content, In computation of economics for treatments highest benefit cost ratio was obtained with good quality of irrigation water (1.2), whereas lowest was obtained with $9 \mathrm{EC}$ of irrigation water (0.5) while comparing the variety for highest benefit cost ratio the AVKB 19 (1.1) found higher in comparison to ICMV 15111(0.9). 


\section{Introduction}

Abiotic stresses resulting from water deficit, high salinity, or periods of drought adversely affect plant growth and development and ultimately plant evolution (Inze and Van Montague, 1995). The drought stress poses serious threat to agriculture because of the limitations to control water availability except through costly irrigation strategies (Prabu et al., 2011). Likewise soil salinity is also an aggravating problem for agriculture, affecting the most productive crop areas of the world, those cultivated under irrigation in arid and semiarid regions; they represent $\sim 15 \%$ of global arable land, but produce $>40 \%$ of world food (Munns, 2002; Munns and Tester, 2008). The scarcity of water in association with high salinity is major problem hindering plant growth in these salty lands. Soil and water salinity cause several physiological disorders in plants, connected with the abnormal concentration of ions in the rhizospheric environment; these can range from a cytotoxic and denaturating effect of the ions themselves (Bernstein 1975) to osmotic stress (Greenway and Munns, 1980; Yeo, 1983) and alteration of the ion uptake balance (Rains, 1972; Flowers and Lauchli, 1983). By an agricultural point of view, the final effect of salinity is the reduction of quality and yield of crops (Van den Berg, et al., 1967; Asch, et al., 2000; Yadav, et al., 2004). Conventional agriculture in these areas is threatened by salinisation or desertification resulting from high evapo-transpiration, faulty irrigation practices and intense land utilization (Qadir et al., 2008). Vast areas of good agricultural land are already saline due to natural or man-made causes, resulting in reduced or no productivity. Inadequate supply of water for irrigation is a major factor limiting crop production in arid and semi-arid regions of our country. This scarcity will further aggravate as the share of agriculture sector is likely to reduce from present 83 to about $65 \%$ by 2050 . In the back drop of this alarming scenario of fresh water supply and to ensure food security to the burgeoning population, agriculture sector has no alternative than to use poor quality water for augmenting irrigation requirement. Groundwater is increasingly exploited to bridge the shortfall in water availability from other sources vis-à-vis the water requirement of crops. The surveys indicate that use of poor quality groundwater in different states of India ranges from $32-84 \%$ of the total groundwater development. This is because of the reason that groundwater in arid regions is largely saline while in semi-arid regions it is sodic in nature. Efforts to increase crop production in arid and semiarid regions are often hindered by shortage of good quality water for irrigation. Additionally, fresh water resources are becoming limited and routine irrigation practices in conventional agriculture are causing a steady increase in soil salinity. This will lead to further desertification of affected areas in the future with concomitant reduction in the yield of crops grown for human and animal consumption. Consequently it has become imperative to search for suitable crop/genotype alternatives and develop ecologically sustainable and economically sound production systems that can use poor quality water and withstand drought on saline lands. Increasing the productivity of water and making safe use of poor quality particularly saline and alkali water will play a vital role in easing competition for scarce water resources, prevention of environmental degradation and provision of food and fodder security. Change in climate is also expected to have significant impact on temperature and composition of atmospheric gases, and thereby availability and quality of water, crop water requirements and their productivity under marginal conditions. Higher temperatures and lesser availability of water with increased 
consumptive use by crops under expected climatic changes are likely to further deteriorate the situation. Direct or primary impacts of these abiotic stresses are usually associated with depleted groundwater levels and surface water availability with consequent reduction in agricultural, livestock and fisheries production.In arid and semi-arid regions, farmers are compelled to use poor quality groundwater to meet irrigation requirement of crops as nearly $32-84 \%$ of the groundwater resources in different states of India are saline/brackish. States like Rajasthan and Haryana do not have sufficient surface water resources for meeting irrigation water requirement and thereby depend on saline/sodic ground water which is $84 \%$ and $62 \%$, respectively in the two states. The farmers of these states have been over exploiting groundwater for supplementing the limited surface water resources. This overmining of groundwater is causing decline in water table at alarming rates in good quality groundwater zones and causing quality deterioration further in these areas. Efforts to increase crop production in arid and semi-arid regions are often hindered by shortage of good quality water for irrigation. Various irrigation management strategies have been proposed for using saline and sodic water for irrigation (Boumans et al., 1988; Minhas et al., 2003; Qadir and Oster 2004; Chauhan et al., 2007; Yadav et al., 2007). Increasing the productivity of water and making safe use of poor quality saline and alkali water will play a vital role in easing competition for scarce fresh water resources, prevention of environmental degradation and provision of food and fodder security. In this context, Pearl millet (Pennisetum glaucum L.) is a promising dual purpose, short duration, quick growing crop with good salinity tolerant characteristics, therefore has an advantage over others cultivated fodder in salt affected areas. Pearl millet has been reported to have high tolerance to salinity and drought thus it can serve as an important crop to ensure good quality fodder for animals in the arid and semi-arid regions of India and elsewhere in the world under similar agro ecologies (Kulkarni et al., 2006; Patel et al., 2008). Several researchers documented that Pearlmillet showed minimum yield reduction under saline environment, thus demonstrating its tolerant nature towards salinity. Therefore, present study was conductively undertaken to access the effect of irrigation water salinity and varieties on grain yield and grain quality of Pearlmillet under north-western IndoGangetic Plains of India.

\section{Materials and Methods}

The present study, was carried out at ICARCSSRI experimental farm, Nain $\left(29^{\circ} 19^{\prime} \mathrm{N}\right.$, $76^{\circ} 47^{\circ} \mathrm{E}$ and $230.5 \mathrm{~m}$ above the mean sea level), Panipat, Haryana, India. The climate of the area is semi-arid, with a mean annual rainfall of $678 \mathrm{~mm} \quad(70-80 \%$ of which received during July-September) with the mean annual evaporation of $1598 \mathrm{~mm}$. The mean minimum, maximum temperature and total rainfall during this study period of kharif 2015 (July-November) was $13.9 \mathrm{oC}, 34.3 \mathrm{oC}$ and $523 \mathrm{~mm}$, respectively. The mean minimum and maximum temperatures, recorded during study period (July to November) at the nearest meteorological observatory are $20.7^{\circ} \mathrm{C}$ and $31.7-{ }^{\circ} \mathrm{C}$, respectively. The soil of experimental site (before kharif 2015) was sandy loam in texture with $8.3 \mathrm{pH}$, Walkley-Black $\mathrm{C}$ (0.30\%), EC (6.65 dS/m), $\mathrm{KMnO}_{4}$ oxidizable $\mathrm{N}(130.4 \mathrm{~kg} / \mathrm{ha}), 0.5 \mathrm{M} \mathrm{NaHCO}_{3}$ extractable $\mathrm{P}$ $(11.6 \mathrm{~kg} / \mathrm{ha})$ and $1 \mathrm{~N} \mathrm{NH}_{4} \mathrm{OAC}$ extractable $\mathrm{K}$ $(248.4 \mathrm{~kg} / \mathrm{ha})$. The experiment was conducted with four main-plot treatments consisting of levels of saline irrigation water [normal $(\sim 0.6$ $\mathrm{dSm}^{-1}$ ) and saline 3, 6 and $9 \mathrm{dS} \mathrm{m}^{-1}$ water] and two sub-plot treatments of pearlmillet verities [AVKB-19 and ICMV-15111]. The experiment was designed in split-plot 
arrangements with four replications. The each experimental unit consisted of $4.5 \mathrm{~m} \times 4.5 \mathrm{~m}$ plots. The field was deep ploughed by chisel plough to break the hard pan below the plough layer before start of the experiment. The pearlmillet cv AVKB-19 and ICMV15111 were sown with a seed rate of $12 \mathrm{~kg} / \mathrm{ha}$ during second fortnight of July in 2015 with a row spacing of $30 \mathrm{~cm}$ and plant to plant distance at $10 \mathrm{~cm}$. The pearlmillet crop was harvested at the 9th November 2015.A common dose of nutrients amounting $120 \mathrm{~kg}$ $\mathrm{N}+60 \mathrm{~kg} \mathrm{P}_{2} \mathrm{O}_{5}+40 \mathrm{~kg} \mathrm{~K}_{2} \mathrm{O}$ were applied in all treatments. The $1 / 3 \mathrm{rd} \mathrm{N}$ and whole $\mathrm{P}_{2} \mathrm{O}_{5}$ and $\mathrm{K} 2 \mathrm{O}$ was applied as basal, while remaining $2 / 3$ rd $\mathrm{N}$ was top dressed as urea in two equal splits at 1 st cutting and 30 days after 1st cutting. In view of best weed management, two hand weeding at 20 DAS and 30 DAS after 1st cutting was done to control weeds. The first cut of crop was taken at (50 DAS) at the $8-10 \mathrm{~cm}$ above the ground level. Then the crop was left for grain production. The Final cut was taken at 110 DAS for grain purpose. The biometric observations viz, plant population were counted per meter row length of each plot, remaining like plant height, number of leaves/plant, number of tillers/plant, stem girth were recorded from 5 representative (tagged) plants from each plot at 50DAS and $30 \mathrm{DA} 1 \mathrm{st}$ cut and $60 \mathrm{DA} 1 \mathrm{st}$. The yield attributes viz, number of effective tillers/plant, earhead length, earhead girth, 1000-grain weight, number of grain/earhead were recorded at final harvest. The grain yield was recorded per plot and then calculated per hectare. The representative grain sample (250 gram weight) was taken from grain of each plot to estimating chemical/quality parameters. The samples were dried in hot air oven and ground to pass through $2 \mathrm{~mm}$ sieve for determination of proximate analysis (AOAC, 2005) and cell wall constituents (Van Soest, 1991). All data recorded were analyzed with the help of analysis of variance
(ANOVA) technique (Gomez and Gomez 1984) for split-plot design using SAS 9.3 software (SAS Institute, Cary, NC). The least significant test was used to decipher the main and interaction effects of treatments at $5 \%$ level of significance $(\mathrm{P}<0.05)$.

\section{Results and Discussion}

\section{Growth parameters}

\section{Number of plants}

The number of plants per metre row length (m.r.1.) or per unit area is the major deciding factor for growth and yield of any crop. The effects of irrigation water salinity (from 0.6 to $9 \mathrm{dS} / \mathrm{m}$ ) considerably reduced survival of plants as presented in table 1 .

Between varieties, though the number of plants/m.r.1 in AVKB-19 were higher at all the stages (50DAS, 30 DA 1st cut and 60 DA 1st cut) but achieved significant difference only at $30 \mathrm{DA} 1 \mathrm{st}$ cut stage. In case of use of 6.0 and $9.0 \mathrm{dS} / \mathrm{m}$, reduction was a significant at all the three periodic observations. However, among different salinity levels, use of $3.0 \mathrm{dS} / \mathrm{m}$ water significantly reduced the number of plants/m.r.l. at 30 DA 1st cut stage only as compared to good quality water. Overall at 50 DAS, a reduction in percentage of 4.5, 12.3 and 30.1 were recorded with use of $3.0,6.0$, and $9.0 \mathrm{dS} / \mathrm{m}$ saline water, respectively over control. While respective reductions (\%) at 30 and 60 DA 1st cut were 7.1, 18.3 and 37.6 and 11.5, 22.1 and 46.7, respectively over the control. Interaction effects of varieties and irrigation water salinity on no. of plants/m.r.l. were nonsignificant at all stages. The reduction in plant population might be due to the combined effect of osmotic stress and specific ion toxicity leading to the death of the seedlings Haung et al., (1995). Salinity can disrupt the normal equilibrium of physiological processes 
in plant, leading to death. Our results for the adverse effect of salinity causing reduced germination and poor survival (\%) of crop plants are in close agreement with Poljakaff, (1975) and Zhapayev et al., (2015) for soil salinity in marginal land.

\section{Number of leaves per plant}

Number of leaves per plant is an important index of plant growth and development which determines the capacity of plant to harvest the solar radiation for photosynthesis. The observations with respect to this important plant growth parameter have been shown in Table 1. Across all salinity levels of irrigation water, the highest numbers of leaves were observed in AVKB-19 compared to ICMV15111 at all periodic growth observations. The highest mean number of leaves per plant at 50 DAS, 30 DA 1st cutting and 60 DA 1st cutting were 75.07, 44.46 and 68.62, respectively recorded under good quality water irrigation; whereas the minimum at respective stages were 39.12, 21.62 and 41.28 recorded with use of $9.0 \mathrm{dS} / \mathrm{m}$ water for irrigation. The magnitude in reduction (\%)for number of leaves at 50 DAS, 30 and 60 DA 1st cut stage was $10.89,29.65$ and $47.89 ; 9.95$, 22.84 and 51.37; and 10.29, 22.27, and 39.83 in $3.0,6.0$ and $9.0 \mathrm{dS} / \mathrm{m}$ of saline water irrigation, respectively as compared to good quality water irrigation. The difference in number of leaves was observed at par between control $(0.6 \mathrm{dS} / \mathrm{m})$ and $3.0 \mathrm{dS} / \mathrm{m}$ at 50 DAS and 60 DA 1st cutting stage except 30 DA 1st stage; however, reduction was significant at all periodic observation when irrigation water salinity increased from 6.0 to $9.0 \mathrm{dS} / \mathrm{m}$. The reduction in no. of leaves with increase in salinity levels may be due to reduce opportunity for water absorption also termed as physiological drought. Several similar results of depressing effect of salinity on different plant growth parameters has also been reported by (Abdul et al., 1988; Heakal et al., 1990; Abu-Awwad et al., 2001; Hussein et al., 2010; Nadaf et al., 2010).

\section{Number of tillers per plant}

The observations on number of tillers per plant, which is an index of plant growth and development to compensate for lower plant population, are presented in Table 2.Irrespective of irrigation water salinity levels, mean performance of genotypeAVKB19 was showed statistically higher (7.69) than ICMV 15111 (5.22) at 50DAS, while contrast results at 30 and 60DA 1 st cut stage, ICMV 15111 recorded higher tillers/plant than AVKB-19. At 50 DAS, the highest (7.83) mean number of tillers/plant was recorded with good quality water irrigation. At $30 \mathrm{DA}$ $1 \mathrm{st}$ cut stage, $3.0 \mathrm{dS} / \mathrm{m}$ saline water irrigation produced at par (2.96) mean number of tillers to that (3.23) with use of good quality water but number of tillers/plant were 2.44 at 6.0 $\mathrm{dS} / \mathrm{m}$ and differed significantly 1.90 at 9.0 $\mathrm{dS} / \mathrm{m}$ salinity level. However, at $60 \mathrm{DA} 1 \mathrm{st}$ cut stage, significantly more tillers/plant (5.08) were recorded with good quality water than 4.70 and 4.04 with irrigations using 3.0 and $6 \mathrm{dS} / \mathrm{m}$ saline water, respectively. Thus, At all periodic observation stages, the magnitude in reduction for mean number of tillers/plant was non-significant when irrigation water salinity increased from 0.6 to $3.0 \mathrm{dS} / \mathrm{m}$ but with further increase in salinity to 6.0 and $9.0 \mathrm{dS} / \mathrm{m}$, reduction in percentage were significant i.e. 22.40 and 38.10 at 50 DAS, 24.47 and 41.08 at 30 DA 1st cut stage and 20.54 and 36.82 at 60 DA 1st cut stage, respectively. Among all levels of irrigation water salinity, irrigation with $9.0 \mathrm{dS} / \mathrm{m}$ saline water produced significantly lowest tillers/plant i.e.3.45 and3.21 at 30 and 60 DA 1 st cut, respectively. These findings are in agreement with the earlier observations of Ahmed, et al., (2010) and Nadaf et al., (2010), who reported that increasing salinity levels of irrigation water and soil decreased number of tiller in pearl millet. 


\section{Plant height}

Plant height is a reliable index of plant growth and represents the infrastructure build up over a period. Plant height is one of the important growth parameters contributing to green yield particularly in fodder crops. Plant height represents index of growth and development indicating the build-up of plants. Plant height is genetically controlled parameter but it can be managed to our favour by following improved agronomic practices. The observation with respect to plant height is presented in Table 2.Plant height at all 3 different growth stages was showed significantly higher in "AVKB 19" than ICMV 15111. This may be due to difference in potential of tolerance in pearl millet genotypes to salinity (Gupta et al., 1987; Ashraf and Mcneilly, 1987) difference in seedling adult stage (Alam and Naqvi, 1991; Albassam, 2001) in which it was clear differential response against salinity among the pearl millet cultivars were found. The maximum plant height was observed in good quality water i.e. $194.27 \mathrm{~cm}$ (50 DAS), 88.49 $\mathrm{cm}$ (30 DA 1st cut stage) and $120.5 \mathrm{~cm}$ (at 60 DA 1st cut stage) and minimum of $(129.25 \mathrm{~cm}$ (50 DAS), $51.39 \mathrm{~cm}$ (30 DA 1st cut) and $84.17 \mathrm{~cm}$ (at $60 \mathrm{DA} 1 \mathrm{st}$ cut stage) with saline irrigation water of $9 \mathrm{dS} / \mathrm{m}$. The mean plant height was significantly higher in good quality water as compared to higher levels of saline irrigation water $(3,6,9 \mathrm{dS} / \mathrm{m})$ at 50 DAS. In case of 30 and 60 DA 1st cut plant height was significantly higher in good quality water as compared to 6 and $9 \mathrm{ds} / \mathrm{m}$ but at par difference with salinity level of $3 \mathrm{ds} / \mathrm{m}$. The increasing salinity levels had progressively decreased plant height which may be due to decrease in leaf area because of $\mathrm{Na}+$ toxicity, water and nutrient stress (Bingham 1973). The decrease in leaf area might have resulted in decrease in photosynthates production which in turn reduced plant height. Our findings were supported by Al-Busaidi et al., (2010);
Ahmed et al., (2010); Nadaf et al., (2010) ; Yakubu et al., (2010).

\section{Stem girth}

The perusal of data on Stem girth from Table 3 have revealed that with increase in each salinity levels from good quality water resulted in reduction of stem girth in pearl millet. At 50 DAS, the mean stem diameter of plants decreased by $9.71,25.92$ and $40.52 \%$ when irrigated with saline water at 3.0, 6.0 and $9.0 \mathrm{dS} / \mathrm{m}$ salinity water, respectively as compared to good quality water irrigation. Respective decrease in stem girth at 30 and 60 DA 1st cut were 9.51, 18.72 and 39.33, and $4.18,10.91$ and $21.42 \%$. Irrespective of salinity level in irrigation water, the mean maximum girth was recorded in AVKB-19 variety i.e, $23.08 \mathrm{~mm}$ at $50 \mathrm{DAS}, 17.72 \mathrm{~mm}$ at 30 DA 1st cut and $19.48 \mathrm{~mm}$ at60 DA 1st cut stage in comparison to $19.62,16.84$ and 19.41 $\mathrm{mm}$ recorded at respective stages in ICMV15111. Statistical analysis of data for stem diameter at 50 DAS, 30 and 60 DA 1st cutting stage indicated significant reduction with 6.0 and $9.0 \mathrm{dS} / \mathrm{m}$ salinity water irrigation over the good quality water. The reduction in stem diameter might be due to harmful effects of salinity which suppressed division and enlargement of cells, narrowing of the xylem vessels, and reduced cell size of both the xylem and phloem. Similar results were also obtained by Akram et al., (2002), Ghoulam, et al., (2002) and Lacerda et al., (2003) on stem anatomical characteristics subjected to increasing salinity.

\section{Yield and Yield Attributes}

\section{Number of effective tillers per plant}

The data on the number of effective tillers per plant are depicted in table 4 . The effect of irrigation water salinity indicated that number of effective tillers per plant in both varieties decreased with increasing salinity of irrigation 
water. Good quality water recorded mean maximum (4.25) number of effective tillers per plant, whereas, irrigation water with EC of $9.0 \mathrm{dS} / \mathrm{m}$ recorded minimum (3.23). Over all, the reduction in percentage was 5.88 , 12.47 and 23.88 at $3.0,6.0$, and $9.0 \mathrm{dS} / \mathrm{m}$, respectively as compared to that of good quality water. It is pertinent to note that the reduction in mean number of effective tillers was non-significant up to $6.0 \mathrm{dS} / \mathrm{m} \mathrm{EC}$ in irrigation water but it was found significant at $9.0 \mathrm{dS} / \mathrm{m}$ salinity of irrigation water. However, the mean number of effective tiller was significantly higher in AVKB-19 (4.02) in comparison to ICMV-15111(3.58). Similar results were also reported by Al-Tahir et al., (1997) in barley that increasing levels of soil and water salinity decreased the number of effective tillers per plant.

\section{Ear head length}

Comparison of ear head length (Table 4) in response to saline water irrigation between the two varieties has shown that AVKB-19 performed non-significantly better $(26.88 \mathrm{~cm})$ compared to ICMV-15111 $(24.94 \mathrm{~cm})$. The overall panicle length decreased with all increasing salinity of irrigation water but the reduction was non-significant compared to good quality water at all salinity levels. The maximum ear head length $(27.93 \mathrm{~cm})$ was observed in good quality water irrigation and the minimum $(23.32 \mathrm{~cm})$ in high saline $(9.0$ $\mathrm{dS} / \mathrm{m}$ ) irrigation water. Increasing salinity in irrigation water i.e. 3.0, 6.0 and $9.0 \mathrm{dS} / \mathrm{m}$ reduced ear head length by $3.76,8.63$ and $16.50 \%$, respectively over good quality water. The observed results that increasing salinity levels in water reduced yield related traits are similar to earlier findings of Kumawat et al., (1991).

\section{Ear head girth}

Statistical analysis of data indicated that ear head girth reduced significantly with every successive increase of salinity level of irrigation water over good quality water. The mean maximum ear head girth $(8.38 \mathrm{~cm})$ was obtained with good quality water followed by $8.08,7.35$, and $6.75 \mathrm{~cm}$ (minimum) obtained at 3.0, 6.0 and $9.0 \mathrm{dS} / \mathrm{m}$ irrigation water salinity levels, respectively (Table 4).Irrespective of irrigation water salinity levels, among genotypes, the AVKB-19 produced ear heads with significantly higher $(7.87 \mathrm{~cm})$ girth than that of ICMV-15111 $(7.41 \mathrm{~cm})$. However, the ear head girth reduced by $3.58,12.23$ and $19.44 \%$ with increasing salinity of irrigation water to 3.0, 6.0 and $9.0 \mathrm{dS} / \mathrm{m}$, respectively over control. Similar results reported by Gundalia et al., (1992); that yield and yield related traits reduced significantly with increasing salinity water levels.

\section{0-grain weight}

Mean 1000 grain weight of both genotypes was highest $(7.35 \mathrm{~g})$ with good quality water and significantly reduced to $6.75 \mathrm{~g}$ with EC $6.0 \mathrm{dS} / \mathrm{m}$ and further to the lowest $(6.45 \mathrm{~g})$ with $9.0 \mathrm{dS} / \mathrm{m}$ saline water irrigation (Table 4). While comparing good quality water irrigation, reduction in test weight $(6.46 \mathrm{~g})$ was found at par with salinity level of 3.0 $\mathrm{dS} / \mathrm{m}$. However, irrespective of irrigation water quality, variety AVKB-19 produced significantly bolder $(7.25 \mathrm{~g})$ grains in comparison to that of ICMV-15111 (6.60 g).

The mean test weight reduced in percentage by 3.05 (lowest), 8.07 and 12.19 (highest) at 3.0, 6.0 and $9.0 \mathrm{dS} / \mathrm{m}$ salinity levels of irrigation water, respectively as compared to good quality water. The interaction between genotypes and irrigation water salinity was found significant for both varieties at salinity levels of 3.0, 6.0 and $9.0 \mathrm{dS} / \mathrm{m}$, except for ICMV-15111 only at irrigation with $3 \mathrm{dS} / \mathrm{m}$ water salinity where it was at par. Overall interaction was found highly significant for AVKB-19.Our findings are supported by 
Chopra et al., (1993) and Ragab et al., (2008) that with increasing salinity levels

significantly reduced potential yield attributing characteristics.

Table.1 Effect of salinity levels and varieties on periodic No. of plants/meter row length and No. of leaves/plant of pearl millet

\begin{tabular}{|c|c|c|c|c|c|c|}
\hline \multirow[b]{2}{*}{ Treatments } & \multicolumn{3}{|c|}{ No. of plants/meter row length } & \multicolumn{3}{|c|}{ No. of leaves/plant } \\
\hline & $\begin{array}{c}1^{\text {st }} \text { cut }(50 \\
\text { DAS) }\end{array}$ & $\begin{array}{c}30 \mathrm{DA}^{\mathrm{st}} \\
\text { cut }\end{array}$ & $\begin{array}{l}60 \mathrm{DA}^{\text {st }} \\
\text { cut }\end{array}$ & $\begin{array}{c}1^{\text {st }} \text { cut }(50 \\
\text { DAS) }\end{array}$ & $\begin{array}{c}30 \mathrm{DA} 1^{\text {st }} \\
\text { cut }\end{array}$ & $\begin{array}{c}60 \mathrm{DA}^{\mathrm{st}} \\
\text { cut }\end{array}$ \\
\hline \multicolumn{7}{|c|}{ Salinity levels $(\mathrm{dS} / \mathrm{m})$} \\
\hline Control (0.6) & 11.96 & 10.89 & 10.64 & 75.06 & 44.46 & 68.62 \\
\hline 3 & 11.42 & 10.17 & 9.41 & 66.9 & 40.04 & 61.56 \\
\hline 6 & 10.48 & 8.90 & 8.29 & 52.82 & 34.31 & 53.33 \\
\hline 9 & 8.36 & 6.80 & 5.67 & 39.12 & 21.62 & 41.28 \\
\hline SEm \pm & 1.68 & 0.57 & 0.60 & 3.98 & 4.11 & 4.30 \\
\hline $\mathrm{CD}(\mathrm{P}=0.05)$ & 3.49 & 1.19 & 1.24 & 8.28 & 8.54 & 8.95 \\
\hline \multicolumn{7}{|l|}{ Varieties } \\
\hline ICMV-15111 & 10.50 & 8.72 & 8.10 & 52.45 & 33.023 & 52.49 \\
\hline AVKB-19 & 10.61 & 9.65 & 8.90 & 64.5 & 37.19 & 59.99 \\
\hline SEm \pm & 1.19 & 0.41 & 0.42 & 2.81 & 2.90 & 3.04 \\
\hline $\mathrm{CD}(\mathrm{P}=0.05)$ & 2.46 & 0.84 & NS & 5.854 & NS & 6.33 \\
\hline
\end{tabular}

Table.2 Effect of salinity levels and varieties on periodic No. of Tillers/plant and Plant height $(\mathrm{cm})$ of pearl millet

\begin{tabular}{|c|c|c|c|c|c|c|}
\hline \multirow[b]{2}{*}{ Treatments } & \multicolumn{3}{|c|}{ No. of Tillers/plant } & \multicolumn{3}{|c|}{ Plant height $(\mathrm{cm})$} \\
\hline & $\begin{array}{c}1^{\text {st }} \text { cut }(50 \\
\text { DAS })\end{array}$ & $\begin{array}{l}30 \mathrm{DA} 1^{\text {st }} \\
\text { cut }\end{array}$ & $\begin{array}{l}60 \mathrm{DA}^{\mathrm{st}} \\
\text { cut }\end{array}$ & $\begin{array}{l}1^{\mathrm{st}} \text { cut }(50 \\
\text { DAS) }\end{array}$ & $\begin{array}{l}30 \mathrm{DA} 1^{\mathrm{st}} \\
\text { cut }\end{array}$ & $\begin{array}{l}60 \mathrm{DA}^{\mathrm{st}} \\
\text { cut }\end{array}$ \\
\hline \multicolumn{7}{|c|}{ Salinity levels $(d S / m)$} \\
\hline Control (0.6) & 7.83 & 3.23 & 5.09 & 194.28 & 88.49 & 120.5 \\
\hline 3 & 7.07 & 2.96 & 4.70 & 178.53 & 83.75 & 112.8 \\
\hline 6 & 6.08 & 2.44 & 4.04 & 158.25 & 72.35 & 98.13 \\
\hline 9 & 4.85 & 1.90 & 3.21 & 129.25 & 51.39 & 84.17 \\
\hline SEm \pm & 0.84 & 0.26 & 0.27 & 8.38 & 4.72 & 5.59 \\
\hline $\mathrm{CD}(\mathrm{P}=0.05)$ & 1.75 & 0.54 & 0.56 & 17.44 & 9.81 & 11.62 \\
\hline \multicolumn{7}{|l|}{ Varieties } \\
\hline ICMV-15111 & 5.22 & 2.98 & 4.40 & 147.97 & 67.39 & 86.70 \\
\hline AVKB-19 & 7.69 & 2.28 & 4.12 & 182.19 & 80.6 & 121.1 \\
\hline SEm \pm & 0.60 & 0.18 & 0.19 & 5.93 & 3.34 & 3.95 \\
\hline $\mathrm{CD}(\mathrm{P}=0.05)$ & 1.24 & 0.38 & NS & 12.33 & 6.94 & 8.22 \\
\hline
\end{tabular}


Table.3 Effect of salinity levels and varieties on periodic Stem girth $(\mathrm{mm})$ of pearl millet

\begin{tabular}{|c|c|c|c|}
\hline \multirow{2}{*}{ Treatments } & \multicolumn{3}{|c|}{ Stem girth $(\mathrm{mm})$} \\
\hline & $1^{\text {st }}$ cut $(50 \mathrm{DAS})$ & $30 \mathrm{DA} 1^{\text {st }} \mathrm{cut}$ & $60 \mathrm{DA} 1^{\mathrm{st}} \mathrm{cut}$ \\
\hline \multicolumn{4}{|c|}{ Salinity levels $(d S / m)$} \\
\hline Control (0.6) & 26.38 & 20.79 & 23.79 \\
\hline 3 & 23.81 & 18.81 & 21.8 \\
\hline 6 & 19.54 & 16.90 & 18.6 \\
\hline 9 & 15.69 & 12.62 & 13.60 \\
\hline SEm \pm & 2.53 & 1.36 & 1.96 \\
\hline $\mathrm{CD}(\mathrm{P}=0.05)$ & 5.26 & 2.84 & 4.08 \\
\hline \multicolumn{4}{|l|}{ Varieties } \\
\hline ICMV-15111 & 19.63 & 16.84 & 19.41 \\
\hline AVKB-19 & 23.08 & 17.72 & 19.48 \\
\hline SEm \pm & 1.79 & 0.96 & 1.39 \\
\hline $\mathrm{CD}(\mathrm{P}=0.05)$ & NS & NS & NS \\
\hline
\end{tabular}

Table.4 Effect of salinity levels and varieties on Yield Attributes and Yield (t/ha) of pearl millet

\begin{tabular}{|c|c|c|c|c|c|c|}
\hline \multirow[b]{2}{*}{ Treatments } & \multicolumn{6}{|c|}{ Yield Attributes and Yield (t/ha) } \\
\hline & $\begin{array}{c}\text { No. of } \\
\text { effective } \\
\text { tiller/plant }\end{array}$ & $\begin{array}{l}\text { Earhead } \\
\text { length }(\mathrm{cm})\end{array}$ & $\begin{array}{l}\text { Earhead girth } \\
\quad(\mathrm{cm})\end{array}$ & $\begin{array}{l}\text { 1000-grain } \\
\text { weight }\end{array}$ & $\begin{array}{c}\text { No. of } \\
\text { grain per } \\
\text { Earhead }\end{array}$ & $\begin{array}{c}\text { Grain yield } \\
(\mathrm{t} / \mathrm{ha})\end{array}$ \\
\hline \multicolumn{7}{|c|}{ Salinity levels $(\mathrm{dS} / \mathrm{m})$} \\
\hline Control (0.6) & 4.25 & 27.93 & 8.38 & 7.35 & 1869.94 & 2.17 \\
\hline 3 & 4.00 & 26.88 & 8.08 & 7.13 & 1651.13 & 1.95 \\
\hline 6 & 3.72 & 25.52 & 7.36 & 6.76 & 1582.92 & 1.72 \\
\hline 9 & 3.24 & 23.33 & 6.75 & 6.46 & 1336.26 & 1.36 \\
\hline SEm \pm & 0.28 & 1.80 & 0.29 & 0.20 & 53.41 & 0.12 \\
\hline $\mathrm{CD}(\mathrm{P}=0.05)$ & 0.59 & NS & 0.61 & 0.41 & 111.07 & 0.24 \\
\hline \multicolumn{7}{|l|}{ Varieties } \\
\hline ICMV-15111 & 3.58 & 24.95 & 7.41 & 6.60 & 1607.86 & 1.66 \\
\hline AVKB-19 & 4.02 & 26.88 & 7.87 & 7.25 & 1612.26 & 1.93 \\
\hline SEm \pm & 0.20 & 1.27 & 0.29 & 0.14 & 37.76 & 0.08 \\
\hline $\mathrm{CD}(\mathrm{P}=0.05)$ & 0.42 & NS & 0.61 & 0.29 & $\mathrm{NS}$ & 0.17 \\
\hline
\end{tabular}

Table.5 Effect of salinity levels and varieties on Chemical composition (\%) of pearl millet grains

\begin{tabular}{|l|c|c|c|c|c|c|}
\hline \multirow{2}{*}{ Treatments } & \multicolumn{7}{|c|}{ Chemical composition (\%) of grains } \\
\cline { 2 - 7 } & DM & \multicolumn{7}{|c|}{ CP } & Ash & EE & NDF & ADF \\
\hline \multicolumn{7}{|l|}{ Salinity levels $(d S / m)$} \\
\hline Control $(0.6)$ & 89.87 & 10.14 & 2.91 & 4.39 & 32.65 & 5.55 \\
\hline 3 & 90.50 & 10.06 & 2.94 & 4.35 & 32.95 & 5.77 \\
\hline 6 & 91.94 & 9.86 & 2.98 & 4.29 & 33.60 & 6.12 \\
\hline 9 & 94.42 & 9.54 & 3.06 & 4.17 & 34.33 & 6.66 \\
\hline SEm \pm & 1.35 & 0.56 & 0.21 & 0.25 & 0.91 & 0.50 \\
\hline CD $(\mathrm{P}=0.05)$ & 2.80 & NS & NS & NS & NS & 1.04 \\
\hline Varieties & & & & & & \\
\hline ICMV-15111 & 92.58 & 9.65 & 3.10 & 4.21 & 34.09 & 6.08 \\
\hline AVKB-19 & 90.78 & 10.15 & 2.85 & 4.39 & 32.68 & 5.96 \\
\hline SEm \pm & 0.95 & 0.39 & 0.15 & 0.18 & 0.64 & 0.36 \\
\hline CD $(\mathrm{P}=0.05)$ & NS & NS & NS & NS & 1.33 & NS \\
\hline
\end{tabular}


Table.6 Effect of salinity levels and varieties on Chemical composition (\%) of pearl millet grains

\begin{tabular}{|l|c|c|c|c|}
\hline \multirow{2}{*}{ Treatments } & \multicolumn{4}{|c|}{ Chemical composition (\%) of grains } \\
\cline { 2 - 5 } & OM & HC & Cell soluble & T-CHO \\
\hline Salinity levels $(d S / m)$ & \multicolumn{5}{|c|}{} \\
\hline Control $(0.6)$ & 97.09 & 27.98 & 67.35 & 82.56 \\
\hline 3 & 97.06 & 28.29 & 67.05 & 82.66 \\
\hline 6 & 97.02 & 28.74 & 66.40 & 82.86 \\
\hline 9 & 96.94 & 29.41 & 65.67 & 83.23 \\
\hline SEm \pm & 0.21 & 1.16 & 0.91 & 0.66 \\
\hline CD $(\mathrm{P}=0.05)$ & $\mathrm{NS}$ & $\mathrm{NS}$ & $\mathrm{NS}$ & NS \\
\hline Varieties & \multicolumn{5}{|l|}{} \\
\hline ICMV-15111 & 96.90 & 28.70 & 65.91 & 83.04 \\
\hline AVKB-19 & 97.15 & 28.51 & 67.32 & 82.61 \\
\hline SEm \pm & 0.15 & 0.82 & 0.64 & 0.47 \\
\hline CD $(\mathrm{P}=0.05)$ & $\mathrm{NS}$ & $\mathrm{NS}$ & 1.33 & NS \\
\hline
\end{tabular}

Table.7 Effect of salinity levels and varieties on Economics of pearl millet

\begin{tabular}{|c|c|c|c|c|c|c|c|c|c|}
\hline \multirow{2}{*}{$\begin{array}{l}\text { Salinity levels } \\
\text { (dS/m)/ } \\
\text { Varieties }\end{array}$} & \multicolumn{3}{|c|}{ Gross Returns } & \multicolumn{3}{c|}{ Net returns } & \multicolumn{3}{c|}{ B:C Ratio } \\
\cline { 2 - 11 } & $\begin{array}{c}\text { ICMV } \\
15111\end{array}$ & $\begin{array}{c}\text { AVKB } \\
19\end{array}$ & Mean & $\begin{array}{c}\text { ICMV } \\
15111\end{array}$ & $\begin{array}{c}\text { AVKB } \\
19\end{array}$ & Mean & $\begin{array}{c}\text { ICMV } \\
15111\end{array}$ & $\begin{array}{c}\text { AVKB } \\
19\end{array}$ & Mean \\
\hline Control & 91232.5 & 102212.5 & 96722.5 & 50232.5 & 61212.5 & 55722.5 & 1.23 & 1.49 & 1.4 \\
\hline 3 & 83925.0 & 92627.5 & 88276.3 & 42925.0 & 51627.5 & 47276.3 & 1.05 & 1.26 & 1.2 \\
\hline 6 & 74452.5 & 81430.0 & 77941.3 & 33452.5 & 40430.0 & 36941.3 & 0.82 & 0.99 & 0.9 \\
\hline 9 & 59837.5 & 65235.0 & 62536.3 & 18837.5 & 24235.0 & 21536.3 & 0.46 & 0.59 & 0.5 \\
\hline Mean & 77361.9 & 85376.3 & & 36361.9 & 44376.3 & & 0.9 & 1.1 & \\
\hline
\end{tabular}

\section{Number of grain per ear}

Varietal differences for mean number of grain per ear head were found 4.40 and non significantly higher $(0.28 \%)$ in AVKB-19 (1612.26) as compared to that of ICMV15111(1607.86) (Table 4). The highest mean numbers of grain/ear head were 1869.94 when irrigated with good quality water, while minimum recorded with use of $9 \mathrm{dS} / \mathrm{m}$ salinity water.

Overall the interaction between varieties and salinity levels was found significant at all salinity levels and varieties except at $3 \mathrm{dS} / \mathrm{m}$ in case of ICMV 15111. The extent of reduction in number of grains with increasing salinity levels from good quality was 11.70, 15.34 and $28.54 \%$ at 3.0, 6.0 and $9.0 \mathrm{dS} / \mathrm{m}$, respectively in comparison to good quality water.

\section{Grain yield}

The overall effect of salinity was highly significant on grain yield of both the varieties of pearl millet. The observations revealed that grain yield were strongly affected by all saline water irrigation treatments over good quality water. Increase in the salt concentrations of irrigation water from good quality to EC 9.0 $\mathrm{dS} / \mathrm{m}$ caused significant decrease in grain yield (Table 4). The significant reduction $(37.44 \%)$ was observed mainly at the higher salinity $(9 \mathrm{dS} / \mathrm{m})$ of irrigation water compared to the good quality water, whereas, it was 9.90 and $20.80 \%$ at EC 3.0 and $6.0 \mathrm{dS} / \mathrm{m}$, respectively. Genotype AVKB-19 produced significantly higher $(16.26 \%)$ mean grain yield of $1.93 \mathrm{t} / \mathrm{ha}$ as compared to $1.66 \mathrm{t} / \mathrm{ha}$ in ICMV-15111, and thus has potential to grow 
in saline environment. Significantly highest $(2.17 \mathrm{t} / \mathrm{ha})$ mean grain yield was recorded with good quality water in comparison to $1.95,1.72$ and $1.35 \mathrm{t} / \mathrm{ha}$ achieved with irrigation using 3.0, 6.0 and $9.0 \mathrm{dS} / \mathrm{m}$ salinity water, respectively.

The magnitude of reduction in percentage with increasing salinity over good quality irrigation water was reported $10.14,20.74$ and 37.33 with $3.0,6.0$ and $9.0 \mathrm{dS} / \mathrm{m}$ salinity water, respectively. Decrease in grain yield by increasing salinity of irrigation water may be due to more negative water potential of soil solution causing reduced water and nutrient uptake consequently lower leaf area development in turn reduced net assimilates. Shani et al., (2001) also related the yield loss to reduced photosynthesis, high energy and carbohydrate expenses in osmoregulation, and interference with cell functions under saline conditions. Ghadiri et al., (2005) reported restricted water uptake by salinity due to the high osmotic potential in the soil and high concentrations of specific ions that may cause physiological disorders in the plant tissues and reduce yields. These results are substantiated by Zahid et al., (1986), Francois et al.,(1988), Kulkarni et al., (2006), Yadav et al., (2007), Hussein et al., (2010), Heidari, et al., (2011), Krishnamurthy et al., (2014).

\section{Chemical composition of grain}

\section{Dry matter content}

Dry matter content of pearl millet grains increased with increasing levels of irrigation water salinity levels, but the mean dry matter content increased significantly highest by $5.06 \%$ with saline EC $9.0 \mathrm{dS} / \mathrm{m}$ water irrigation as compared with that of good quality water irrigation (Table 5). The mean performance of pearl millet with respect to this parameter was found the maximum $(94.42 \%)$ at EC $9.0 \mathrm{dS} / \mathrm{m}$ water irrigation but minimum dry matter content $(89.97 \%)$ recorded with good quality irrigation water. The magnitude of increase in dry matter content of pearlmillet grains with increasing salinity levels was recorded $0.70,2.30$ and $5.06 \%$ using 3.0, 6.0 and $9.0 \mathrm{dS} / \mathrm{m}$ salinity water, respectively over good quality irrigation water. Irrespective of quality of water, the mean maximum dry matter content in grains was relatively higher in ICMV $15111(92.58 \%)$ variety than AVKB 19 $(90.78 \%)$. The higher uptake and accumulation of ions such as $\mathrm{Na}, \mathrm{K}, \mathrm{Ca}$ and $\mathrm{Mg}$ under saline environment might be resulted into higher dry matter content with increased salinity of irrigation water.

\section{Crude protein content}

There was non-significant decrease in crude protein content of pearl millet grains with increasing levels of irrigation water salinity. Perusal of the data in Table 5 indicated that the mean maximum crude protein content was recorded with good quality water irrigation $(10.14 \%)$, whereas, minimum crude protein content was recorded with $9.0 \mathrm{dS} / \mathrm{m}$ EC irrigation water (9.54). While comparing the potential of two genotypes, regardless of irrigation water salinity levels, crude protein content in grains of variety AVKB 19 $(10.15 \%)$ was relatively higher than ICMV $15111(9.65 \%)$ but differences remained nonsignificant. The reduction in protein content at higher salinity levels may be due to the fact that the higher salt load over plant root zone reported to reduce the root area which lowers down the uptake of nitrogen by the plants which ultimately leads to lower crude protein content in plant biomass as it is essential for protein synthesis.

\section{Total ash content}

Main effect of irrigation water salinity indicated that total ash content in pearl millet grains increased steadily with increasing levels of salinity in irrigation water (Table 5). 
Increased ash content with any agronomic intervention is welcome if concentration of major cations $(\mathrm{Na}+, \mathrm{Ca} 2+, \mathrm{Mg} 2+)$ and anions (Cl- SO4 2-) increases in required proportion which favours the human as well as animal health, as supplementation of mineral mixture is common practice from nutrition point of view. Mean minimum total ash content $(2.91 \%)$ recorded with good quality water irrigation whereas the mean maximum $(3.06 \%)$ recorded from $9.0 \mathrm{dS} / \mathrm{m}$ EC water use for irrigation. The increase in total ash content was found highest $(5.15 \%)$ with 9.0 $\mathrm{dS} / \mathrm{m}$ EC water irrigation over the good quality water. The non-significant increase in total ash content was found with every increment of salinity level in irrigation water. Irrespective of water quality, slightly higher total ash content was recorded from ICMV $15111(3.1 \%)$ than AVKB 19 (2.85\%).Application of irrigation water of EC $9.0 \mathrm{dS} / \mathrm{m}$ irrigation water attributed to relatively higher uptake of soluble salts which affected total ash content in positive manner as their higher concentration favour ash yield.

\section{Ether extract content}

Ether extract content though decreased, but non-significantly, with increasing levels of irrigation water salinity. Across the salinity levels, ether extract content in variety AVKB 19 was found higher $(4.39 \%)$ than that of ICMV 15111 (4.21\%) (Table 5). While visualising the influence of irrigation water salinity levels on pearl millet grains, minimum ether extract content was found with $9.0 \mathrm{dS} / \mathrm{m} \mathrm{EC} \mathrm{(4.17 \% ),} \mathrm{whereas} \mathrm{the}$ maximum $(4.39 \%)$ with good quality water. The percentage reduction in ether extract content was found maximum (5.01) with 9.0 $\mathrm{dS} / \mathrm{m}$ EC irrigation water as compared to good quality water, but reduction with each increment of salinity level was nonsignificant. Higher concentration of soluble salts in the root zone as result of irrigation with higher saline water may adversely affected the physiological function of the pearlmillet which ultimately resulted into lower ether extract with increased level of salinity.

\section{Neutral detergent fibre}

Neutral Detergent Fibre (NDF) mainly consists of hemi-cellulose, cellulose and lignin. From feeding point of view low NDF is a desirable parameter of fodder as well as grains. The data on neutral detergent fibre content in grains as affected by different irrigation water salinity levels are depicted in Table 5. NDF content of grains increased marginally with every increase in level of irrigation water salinity. The maximum NDF content of $34.33 \%$ was recorded with 9.0 $\mathrm{ds} / \mathrm{m}$ EC water for irrigation as compared to the minimum of $32.65 \%$ observed with good quality water irrigation. The increase in NDF content was found highest with $9.0 \mathrm{dS} / \mathrm{m} \mathrm{EC}$ of irrigation water over good quality water with $(5.15 \%)$, but increase in NDF content from every increasing salinity level was found non-significant. When genotypes were compared, genotype ICMV 15111 responded significantly higher with $(34.09 \%)$ than AVKB 19 with $(32.68 \%)$. This might be due to differential response of genotypes for accumulation of salt in stress conditions. Higher NDF content with saline water irrigation may be ascribed to the fact that higher concentration of soluble salts might have deposited in cell wall making it more rigid and hard. Ben-Ghedalia et al., (2001) also reported that NDF content responded positively to increase in water salinity.

\section{Acid detergent fibre content}

The data on ADF percentage as affected by irrigation water salinity levels are presented in Table 5. Perusal of the data revealed that among different irrigation water salinity 
levels, ADF content followed the trends as that of NDF content. Acid detergent fibre content in grains of pearl millet increased slightly with increasing levels of irrigation water salinity. The maximum ADF content was recorded with $9.0 \mathrm{dS} / \mathrm{m}$ EC of irrigation water $(6.66 \%)$, whereas minimum was recorded with good quality water irrigation $(5.55 \%)$. Across different salinity levels in irrigation water, variety ICMV 15111 found containing relatively more ADF content of $6.08 \%$ in its grain than $5.96 \%$ in AVKB 19. The significant increase $(\%)$ of $3.87,10.18$ and 20 was recorded with 3.0, 6.0 and 9.0 $\mathrm{dS} / \mathrm{m}$ EC water irrigation, respectively over good quality water. Deposition of higher contents of soluble salts in cell might have made it more rigid and hard, so acid detergent fibre content increased at higher EC of irrigation water.

\section{Organic matter}

Organic matter and total mineral content makes the total composition of any plant material. The data on organic matter content as affected by irrigation water salinity levels are shown in Table 6. Organic matter content decreased with increasing levels of irrigation water salinity. The maximum organic matter content was recorded with good quality water use for irrigation (97.09\%), whereas minimum $(96.94 \%)$ observed with $9.0 \mathrm{dS} / \mathrm{m}$ EC water $(96.94 \%)$. The decrease in organic matter content was non-significant up to the highest level of $9.0 \mathrm{dS} / \mathrm{m}$ salinity water for irrigation.

Between the cultivars, the ICMV 15111 recorded lower viz., $96.90 \%$ organic matter content than $97.15 \%$ in AVKB 19. Increased irrigation water salinity increased the total ash content of plant and plant materials due to higher uptake of salts from soil solution to adjust against osmotic stress, so fraction of organic matter decreased simultaneously at higher EC.

\section{Hemi-cellulose content}

Hemi cellulose content was derived from NDF after deducting ADF content from it. The data on hemi-cellulose content as affected by different irrigation water salinity levels are presented in Table 6.With increasing levels of irrigation water salinity, the hemi-cellulose content increased nonsignificantly. The maximum hemi-cellulose content $(29.41 \%)$ was recorded with $9.0 \mathrm{dS} / \mathrm{m}$ EC water irrigation water, whereas minimum hemi-cellulose $(27.95 \%)$ was recorded with good quality water irrigation. While comparing the two varieties, it was found that ICMV 15111 contained slightly higher hemicellulose content of $28.7 \%$ than AVKB 19 with $28.50 \%$.

\section{Cell soluble content}

Cell soluble content decreased slightly with increasing levels of irrigation water salinity in pearl millet grains (Table 6). Minimum Cell soluble content was recorded with 9 EC of irrigation water $(65.67 \%)$, whereas maximum soluble content was recorded with good quality water irrigation (67.35\%). The maximum reduction $(2.49 \%)$ in cell soluble constituents was found with $9 \mathrm{EC}$ of irrigation water over good quality water. The change in Cell soluble content with respect to every levels of increasing salinity was statistically non-significant. It followed the same trend as crude protein content, ether etc. with increasing salinity levels. Irrespective of water salinity levels cell soluble constituent was found significantly higher from AVKB $19(67.32 \%)$ than ICMV 15111(65.91\%).

\section{Total carbohydrate content}

Total carbohydrate content in pearl millet grains increased only slightly with increasing levels of irrigation water salinity. The maximum total carbohydrate content was recorded from use of $9.0 \mathrm{dS} / \mathrm{m}$ EC irrigation 
water $(83.23 \%)$ whereas minimum total carbohydrate content was recorded with good quality water irrigation water (82.56\%) (Table6). The increase in total carbohydrate content with saline water irrigation was statistically non-significant for every increasing level of salinity. When comparing the varietal differences for this parameter, ICMV 15111 was recorded slightly higher i.e. $83.04 \%$ than $82.61 \%$ in AVKB 19. Irrigations using $9.0 \mathrm{dS} / \mathrm{m}$ EC water adversely affected crude protein, ether extract content and yield due to higher concentration of soluble salts in soil solution but fraction of total carbohydrates increased simultaneously.

\section{Economics of production}

The data on cost of cultivation, gross returns, net returns and benefit cost ratio (B:C) as influenced by saline water irrigation level sare presented in Table 7.Cost of cultivation was taken as same for all the saline water treatments because of consideration of natural availability of different salinity. In general gross returns, net return, benefit cost ratio was found higher for AVKB19 and for good quality irrigation water treatment. Highest gross returns ( 96722.5/ha) were recorded under the good quality water irrigation and the lowest $(\sim 62536.3 / \mathrm{ha})$ with $9 \mathrm{EC}$ of irrigation water. This can be ascribed to lower grain yield due to saline water irrigation. Irrespective of water quality the mean gross return was found highest in AVKB 19 ( 85376.3)thanICMV15111 ( 77361.9). While higher net return $(\sim 44376.3)$ was also obtained from variety AVKB 19 comparison with ICMV $15111 \quad(\sim$ 36361.3), for investigating the effect of water quality good quality irrigation water recorded highest net return than higher levels of salinity.

Highest mean performance for benefit cost ratio was obtained with good quality of irrigation water (1.2), whereas lowest was obtained with $9 \mathrm{EC}$ of irrigation water (0.5) while comparing the variety for highest benefit cost ratio the AVKB 19 (1.1) found higher in comparison to ICMV 15111(0.9). The difference among the cultivar performance might be due to wide genetic variability for salinity tolerance. The magnitude of the reduction in percentage over good quality irrigation water for the benefit cost ratio was found $14.28,35.72$ and 64.28 with 3.0, 6.0 and $9.0 \mathrm{dS} / \mathrm{m} \quad \mathrm{EC}$ water irrigation, respectively.

In conclusion, our results suggest that AVKB19 genotype of pearlmillet proved superior and may be adapted as a choice for getting higher grain yield with better quality as compare to the ICMV 15111 under saline environment in north-western region of India and elsewhere under similar agro-climatic conditions.

\section{Acknowledgement}

We sincerely acknowledge Director, ICARNDRI for financial support, Director, ICARCSSRI and In-charge, Agronomy section, ICAR-NDRI, Karnal for providing field staff, lab facilities and assistance in conducting this research.

\section{References}

Abdul, K. S., Alkam, F. M. and Jamal, M. A. 1988. Effects of different salinity levels on vegetative growth, yield and its components in barley. Zanco 1(1): 21-32.

Abu-Awwad, A. M. 2001. Influence of different water quantities and qualities on limon trees and soil salts distribution at the Jordan Valley. Agricultural Water Management52: 53-71.

Ahmed, B. O., Inoue, M. and Moritani, S. 2010. Effect of saline water irrigation and manure application on the available water content, soil salinity, and growth of wheat. Agricultural Water Management 9(1): 165-170. 
Akram, M., Akhtar, S., Javed, I. H., Wahid, A. and Rasul, E. 2002. Anatomical attributes of different wheat accession varieties to $\mathrm{NaCl}$ salinity. International Journal of Agriculture and Biology4: 166-168.

Alam, S. M., and Naqvi, S. S. M. 1991. Effect of salinity on growth and nutrient content of pearlmillet grown in desert and gravel. Pakistan Journal of Botany23: 223-226.

Albassam, B. A. 2001. Effect nitrate nutrition on growth and nitrogen assimilation of pearl-millet exposed to sodium chloride stress. Journal of Plant Nutrition24: 13251335.

Al-Busaidi, A., Al-Rawahy, S. A. and Ahmed, M. 2010. Growing tomato in salty soil: Screening response of different tomato cultivars to saline irrigation. Published in the Monograph on Management of SaltAffected Soils and Water for Sustainable Agriculture Mushtaque A, Al-Rawahi SA, Hussain N eds. Sultan Qaboos University, Oman, 25-33.

Al-Tahir, O. A., Al-Nabulsi, Y. A. and Helalia, A. M. 1997. Effects of water quality and frequency of irrigation on growth and yield of barley (Hordeum vulgare L.). Agricultural Water Managemen 34: 1724.

AOAC, 2005. Official Methods of Analysis, 18th edn. Revised. Association of Official Analytical Chemists, Arlington, Virginia, USA.

Ashraf, M. and McNeilly, T. 1987. Salinity effects on five cultivars/lines of pearl millet [Pennisetum americanum L Leeke]. Plant Soil103: 13-9.

Ben-Ghedalia, D., Solomon, R., Miron, J., Yosef, E., Zomberg, Z., Zukerman, E. and Kipnis, T. 2001. Effect of water salinity on the composition and in vitro digestibility of winter-annual ryegrass grown in the Arava desert. Animal feed science and technology 91(3): 139-147.

Bernstein, L. 1975. Effects of salinity and sodicity on plant growth. Annual review of phytopathology 13(1): 295-312.

Bingham, F. T. (1973). Salt tolerance of Mexican wheat: I. Effect of $\mathrm{NO} 3$ and
$\mathrm{NaCl}$ on mineral nutrition, growth, and grain production of four wheats. Soil Science Society of America Journal, 37(5), 711-715.

Boumans, J. H., Van Hoorn, J. W., Kruseman, G. P., and Tanwar, B. S. 1988. Water table control, reuse and disposal of drainage water in Haryana. Agricultural Water Management 14 (1-4): 537-545.

Chauhan, S. K., Chauhan, C. P. S. and Minhas, P. S. 2007. Effect of cyclic use and blending of alkali and good quality waters on soil properties, yield and quality of potato, sunflower and Sesbania. Irrigation Science 26(1): 81-89.

Chopra, N. and Chopra, N. 1993. Relative salt tolerance of pearl millet (Pennisetum glaucum) varieties in Marwar tract of Rajasthan. Indian Journal of Agricultural Research63: 652-654.

Flowers, TJ, \& Lauchli, A. (1983). Sodium versus potassium: substitution and compartmentation. Encyclopedia of plant physiology. New series.

Ghadiri, H., Dordipour, I., Bybordi, M. and Malakourti, M. J. 2005. Potential use of Caspian Sea for supplementary irrigation in North Iran. Agricultural Water Management79: 209-224.

Ghoulam, C., Foursy, A. and Fares, K. 2002. Effect of salt stress on growth, inorganic ions and praline accumulation in relation to osmotic adjustment in fuie sugar beet cultivars. Environmental and Experimental Botany 47: 39-50.

Gomez, K.A. And Gomez, A.A. 1984. Statistical Procedure for Agricultural Research, Willey-Int. Sci. Pub., New York, USA: 60-65.

Greenway, H. and Munns, R. 1980. Mechanisms of salt tolerance in nonhalophytes. Annual review of Plant Physiology 31(1): 149-190.

Gundalia, J. D., Patel, M. S., Polara, K. B. and Tank, N. K. 1992. Relative salinity tolerance of pearl millet genotypes Pennisetum typhoides. Gujarat Agricultural University Research Journal India. 
Gupta, S.C., Lal, P., Muralia, R.N., Kumar, A. and Srivastava, J. P. 1987. Effects of soil salinity and alkalinity on morphophysiological parameters of pearl-millet. Annals of Arid Zone26: 25-32.

Haung, J. and Redmann, R.E. 1995. Salt tolerance of Hordeum and Brassica species during germination and early seedling growth. Canadian Journal of Plant Science 75: 815-819.

Heakal, M. S., Modaihsh, A. S., Mashhady, A. S. and Metwally, A. I. 1990. Combined effects of leaching fraction salinity and potassium content of waters on growth and water use efficiency of wheat and barley. Plant and Soil125: 177-184.

Heidari, M. and Jamshidi, P. 2011. Effects of Salinity and Potassium Application on Antioxidant Enzyme Activities and Physiological Parameters in Pearl Millet. Agricultural Sciences in China10 (2): 228-237.

Hussein, M. M., Kader, A. A., Kady, K. A., Youssef, R. A. and Alva, A. K. 2010. Sorghum response to foliar application of phosphorus and potassium with saline water irrigation. Journal of Crop Improvement 24(4): 324-336.

Indian Grassland and Fodder Research Institute. 2011. Vision: 2030. p.2.

Inze, D. and Montagu, M. V. 1995. Oxidative stress in plants. Current Opinion in Biotech. 6(2): 153-158.

Krishnamurthy, L., Upadhyaya, H. D., Purushothaman, R., Gowda, C. L. L., Kashiwagi, J., Dwivedi, S. L. and Vadez, V. 2014. The extent of variation in salinity tolerance of the minicore collection of finger millet (Eleusine coracana L.) Gaertn. germplasm. Plant Science 227: 51-59.

Kulkarni, V. N., Rai, K. N., Dakheel, A. J., Ibrahim, M., Hebbara, M. and Vadez, V. 2006. Pearl millet germplasm adapted to saline conditions. International Sorghum and Millets Newsletter 47: 103-106.

Kumawat, G. L., Lal, P., Chhipa, B. R. and Kumar, A. 1991. Effect of salinity and sodicity of water used for supplemental irrigation on morphophysiological parameters and yield of pearl millet. Plant Physiology and Biochemistry-New Delhi 18: 43-43.

Lacerda, C. F., Cambraia, J., Cano, M. A., Ruiz, H. A. and Prisco, J. T. 2003. Solute accumulation and distribution during shoot and leaf development in two sorghum genotypes under salt stress. Environmental and Experimental Botany49: 107-120.

Minhas, P. S. and Sharma, O. P. 2003. Management of soil salinity and alkalinity problems in India. Journal of crop production 71-2: 181-230.

Munns, R. and Tester, M. 2008. Mechanisms of salinity tolerance. Annual Review of Plant Bio. 59: 651-681.

Munns, R., Husain, S., Rivelli, A. R., James, R. A., Condon, A. G., Lindsay, M. P., Lagudah, E. S., Schachtman, D. P. and Hare, R. A. 2002. Avenues for increasing salt tolerance of crops, and the role of physiologically based selection traits. Plant Soil247: 93-105.

Nadaf, S. K., Al-Hinai, S. A., Al-Farsi, S. M., Al-Lawati, A. H., Al-Bakri, A. N., Ahmed, M. and Hussain, N. 2010. Differential response of salt tolerant pearl millet genotypes to irrigation water salinity. Published in the Monograph on Management of Salt-Affected Soils and Water for Sustainable Agriculture Mushtaque A, Al-Rawahi SA, Hussain N eds. Sultan Qaboos University, Oman, 4760.

Patel, M.R., Sadhu, A.C., Patel, R.M., Parmar, H.P. and Kher, H. R. 2008.Cutting management in different genotypes of forage bajra during summer season. Res. on Crops9 (2): 325-327.

Poljakaff-Mayber, A., 1975. Plants in saline environment. Ecological Studies15: 1014.

Prabu, G., Kawar, P. G., Pagariya, M. C., \& Prasad, D. T. (2011). Identification of water deficit stress upregulated genes in sugarcane. Plant Molecular Biology Reporter, 29(2), 291-304. 
Qadir, M. and Oster, J. D. 2004. Crop and irrigation management strategies for saline-sodic soils and waters aimed at environmentally sustainable agriculture. Science of the total environment323 (1): 1-19.

Qadir, M., Tubeileh, A., Akhtar, J., Larbi, A., Minhas, P. S., \& Khan, M. A. (2008). Productivity enhancement of salt- affected environments through crop diversification. Land degradation \& development, 19(4), 429-453.

Ragab, A. A. M. M., Hellal, F. A. and El-Hady, M. A. 2008. Irrigation water salinity effects on some soil water constants and plant. In Proceeding of the Twelfth International Water Technology Conference, IWTC12 pp. 1-14.

Rains, D. W. 1972. Salt transport by plants in relation to salinity. Annual review of Plant Physiology 23(1): 367-388.

Shani, U. and Dudley, L.M. 2001. Field studies of crop response to water and salt stress. Soil Science Society of American Journal65: 1522-1528.

Van Soest, P.J., Robertson, J.B., and Lewis, B.A., 1991. Method for dietary fiber, neutral detergent fiber, and non-starch polysaccharides in relation to animal nutrition. J. Dairy Sci. 74(10): 3583-3597.
Yadav R K, Ashok kumar, Lal D. And Batra, L.2004.Yield responses of winter (rabi) forage crops to irrigation with saline drainage water. Exp. Agric. 40:65-75.

Yadav, R. K., Singh, S. P., Lal, D. and Kumar, A. 2007. Fodder production and soil health with conjunctive use of saline and good quality water in ustipsamments of a semiarid region. Land degradation and development 18(2): 153-161.

Yakubu, H., Ngala, A. L., and Dugje, I. Y. 2010. Screening of millet (Pennisetum glaucum L.) varieties for salt tolerance in semi-arid soil of Northern Nigeria. World J. Agric. Sci. 6(4): 374-380.

Yeo, A. R. (1983). Salinity resistance: physiologies and prices. Physiologia plantarum, 58(2), 214-222.

Zahid, M. A. Rauf.and A. M. Haqqani. 1986. Study on salt tolerance on Wheat. Pakistan Journal of Agricultural Research 7: 160-163.

Zhapayev, R., Toderich, K., Popova, V., Tautenov, I., Umirzakov, S., Bekzhanov, S., and Karabayev, M. (2015). Forage Production and Nutritional Value of Sorghum and Pearl Millet on Marginal Lands on Priaralie. J. of Arid Land Studies 25(3):169-172.

\section{How to cite this article:}

Govind Makarana, R.K. Yadav, Rakesh Kumar, Ashwani Kumar, P. Sheoran, Gajendra Yadav, Pooja Gupta Soni, Taramani Yadav, Malu Ram Yadav, Manish Kushwaha and Gautam, P.B. 2017. Growth, Yield and Grain Quality of Pearl Millet (Pennisetum glaucum L.) Genotypes as Influenced by Salinity of Irrigation Water in North Western Regions of India. Int.J.Curr.Microbiol.App.Sci. 6(6): 2858-2874. doi: https://doi.org/10.20546/ijcmas.2017.606.339 